\title{
Rio Grande an International Boundary River Is Drying up and in Need of Restoration
}

\author{
Kenneth R. Olson ${ }^{1}{ }^{(\mathbb{C}}$, James M. Lang ${ }^{2}$ \\ ${ }^{1}$ Soil Science in Department of Natural Resources, University of Illinois, Urbana, Illinois, USA \\ ${ }^{2}$ Department of Crop Sciences, College of Agricultural, Consumer, and Environmental Sciences, University of Illinois, Urbana, \\ Illinois, USA \\ Email: krolson@illinois.edu
}

How to cite this paper: Olson, K.R. and Lang, J.M. (2021) Rio Grande an International Boundary River Is Drying up and in Need of Restoration. Open Journal of Soil Science, 11, 587-610.

https://doi.org/10.4236/ojss.2021.1112029

Received: November 20, 2021

Accepted: December 11, 2021

Published: December 14, 2021

Copyright (c) 2021 by author(s) and Scientific Research Publishing Inc. This work is licensed under the Creative Commons Attribution International License (CC BY 4.0).

http://creativecommons.org/licenses/by/4.0/

\begin{abstract}
The headwater source of the Rio Grande is in the Colorado San Juan Mountains as it flows southeast and south. The river crosses deserts and steppes, watering rich irrigated agricultural regions as it drains into the Gulf of Mexico near Brownsville, Texas. The river flow pattern is disrupted by hundreds of dams and irrigation diversions, which has left sections of the Rio Grande River dry. The lower Rio Grande Valley including the Rio Grande Delta is heavily irrigated and has become an important agricultural region. Since the mid-1990s, the flow has been reduced to $20 \%$ because of many large diversions, dams and consumption of water by cities and irrigated farmland. Even with a series of 2001 and 2002, Mexico-United States agreements administered by the International Boundary and Water Commission (IBWC) the Rio Grande River had continued to failed to reach the Gulf of Mexico. Mexico and United States share the river. Historically, the Rio Grande has provided limited navigation and border security. There is a need to restore navigation and shipping by creating a lock and dam system from El Paso, Texas and Matamoros, Mexico to the Gulf of Mexico, In addition there is also a need to restore border security for the Lower Rio Grande, an international border river. If the Rio Grande is ever going to recover, it will require a lock and dam system and an increased river flow. The increased flow needs to be achieved by adding additional water from feeder lakes, a water pipeline, and a balanced approach to water management must include efficiency measures and aggressive conservation in urban areas and on irrigated agricultural lands.
\end{abstract}

\section{Keywords}

Big Bend National Park, Mexico Border, Brownsville and Matamoros International Bridge, Port Brownsville, Rift Cross Section, Thornforest, Restoration 


\section{Introduction}

The Rio Grande is drying up and in need of mitigation. The $1600 \mathrm{~m}$ long, Lower Rio Grande River was a natural barrier to illegal immigration between Mexico and United States. Historically the river provided navigation, limited shipping and border security. There is a need to restore Rio Grande water levels to permit navigation shipping and restore border security. The Rio Grande River headwaters are in Colorado (Figure 1) and the river flows along the Mexico-United States border and into the Gulf of Mexico. The watershed area is $472,000 \mathrm{~km}^{2}$ [1] without including the many endorheic basins near the Rio Grande basin. When added, the watershed size is increased to $870,000 \mathrm{~km}^{2}$ [2] and covers $11 \%$ of the continental United States. The river is the natural border between Texas and Coahuila, Chihuahua, Tamaulipas and Nuevo Leon, Mexico [2].

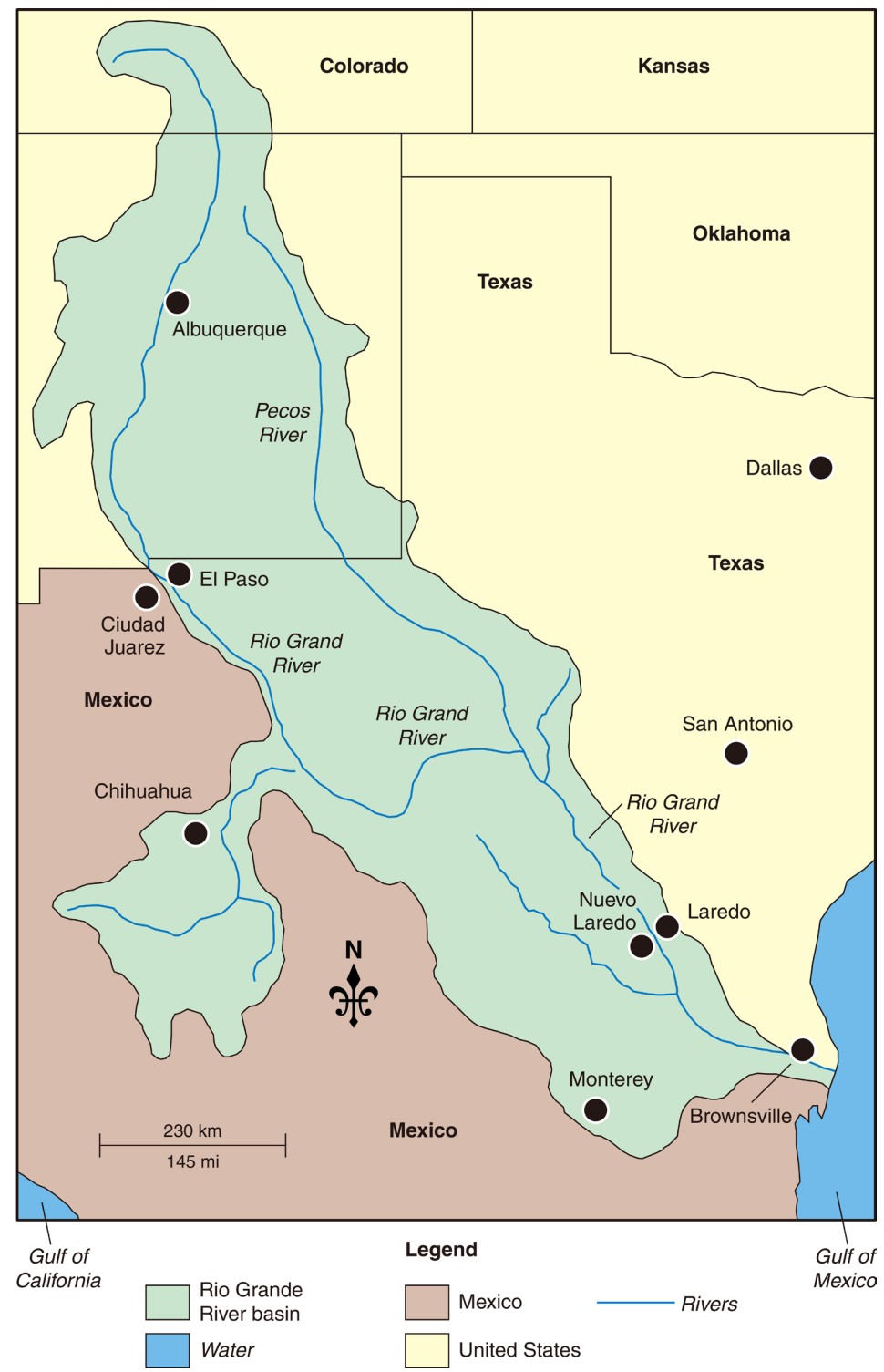

Figure 1. Rio Grande watershed in Mexico and the United States. Map by Mic Greenberg. 
The first good cartography and survey of the Rio Grande River started in 1853 when the international boundary commissioners conducted fieldwork directed by Mexican commissioners and surveyors plus United States equivalents [3]. Between 1850s and 1874, small steamboats navigated the Lower Rio Grande River [2]. A hurricane removed all manmade structures, silting and sandbar formation because of accelerated soil erosion prevented navigation and forced Mexico and United States to spend time and money to adjust the international boundary as a result of changes in the location of the river channel.

During the 1830s and 1840s, there was a border dispute between Mexico and the Republic of Texas. Mexico claimed the border to be Nueces River rather than the Rio Grande River. After Texas had become a state in 1846, this disagreement provided part of rational for the United States invasion of Mexico [4]. Navigation on the Rio Grande was active during much of the 1900s. Over 200 steamboats operated on the Rio Grande River near Brownsville [3]. To restore navigation the engineering challenge would be to create a lock and dam system with feeder lakes and a pipeline to maintain a year-around shipping canal [5] capable of operating in dry periods. The biggest natural obstacles are water supply and elevation change between El Paso and Ciudad Juarez and the Gulf of Mexico. El Paso and Ciudad Juarez are $1100 \mathrm{~m}$ above sea level and the distance from the Gulf of Mexico is approximately $1600 \mathrm{~km}$, with an actual gradient is about 0.75 $\mathrm{m}$ per $\mathrm{km}[3]$.

The primary objectives are: (1) to create a $1600 \mathrm{~km}$ lock and dam system on the Lower Rio Grande, an international border river, between Brownsville, Texas and Matamoros, Mexico and El Paso, Texas and Ciudad Juarez, Mexico to permit year around shipping, navigation and trade and (2) to create a series of feeder lakes, a water pipeline and locks and dams in both the United States and Mexico to enhance the border security by restoring the historically high water levels of the Rio Grande River. This could result in the reduction of the number of illegal immigrants who can walk (rather than swim, boat or float) across the Rio Grande River east of El Paso and Matamoros and reduce the use of soil tunnels under the $1600 \mathrm{~km}$ long Lower Rio Grande River.

\section{Site Location}

The Rio Grande is the $20^{\text {th }}$ longest river in the world and the fifth longest in North America. The total length is $3051 \mathrm{~km}$ with a $3700 \mathrm{~m}$ elevation change as it drops from the Rocky Mountains to sea level at the Gulf of Mexico (Figure 1). Before entering the Gulf Coastal Plain, the Rio Grande cut three canyons (Figures 2-4) to a depth of between 460 to $520 \mathrm{~m}$ across a faulted upland area.

The Rio Grande River tributary water drains through a canyon and forest of spruce (Picea), fir (Abies) and aspen (Populus tremuloides) and into the San Luis Valley. Then it drains into Rio Grande Gorge and White Rock Canyon. It flows into the open terrain of the basin and then through the Mexican Plateau. As the latitude and elevation of the Rio Grande declines, the increasing aridity and temperature of the water produces vegetation including pinion pine (Pinyon 
Pinus, subset Cembroides), juniper (Juniperus) and sagebrush (Artemisia pygmaea) to a hot desert and steppe climate with mesquite (Prosopis), cactus (Lerrea tridentata) (Figure 5), creosote brush and yucca (Yucca). The Texas side of the river is occupied by the Big Bend National Park (Figure 6). The Rio Grande River wanders across the Gulf Coastal Plain and empties into the delta near Brownsville where it joins the Gulf of Mexico (Figure 7).

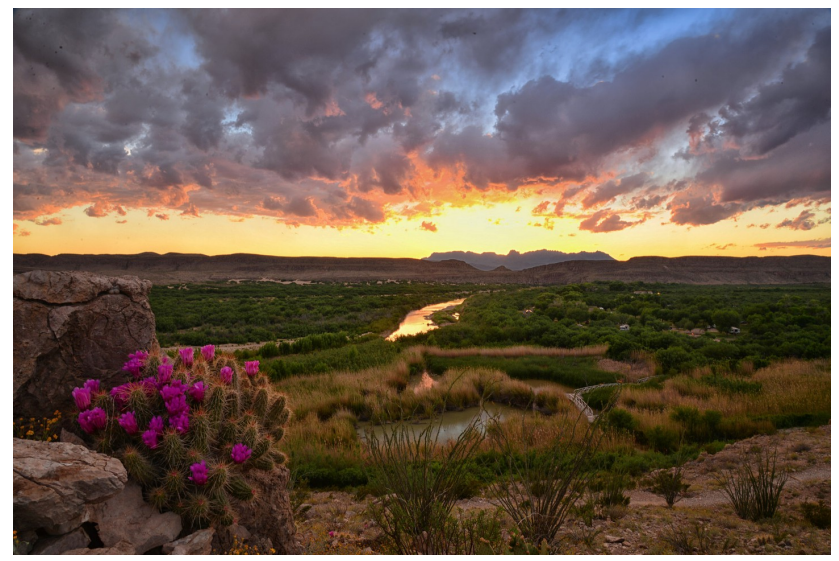

Figure 2. The Rio Grande River flowing through an arid desert.

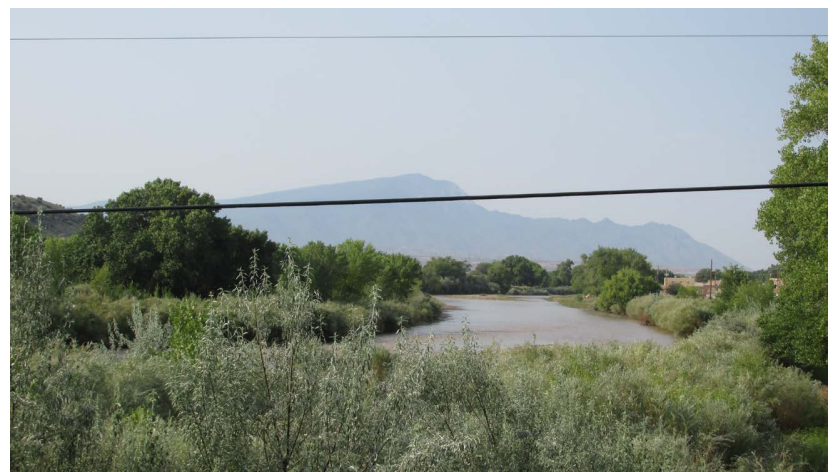

Figure 3. The Rio Grande River north of Albuquerque, New Mexico.

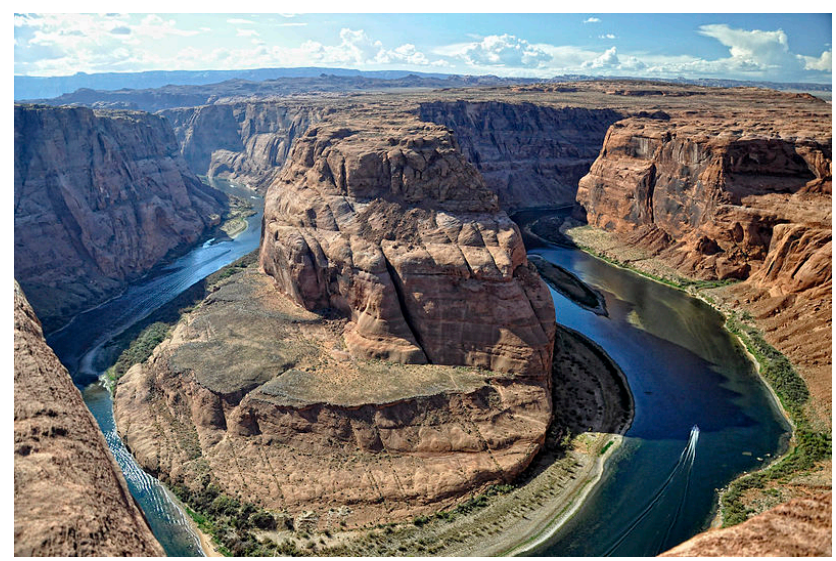

Figure 4. Rio Grande Horseshoe Bend on the Rio Grande River. 


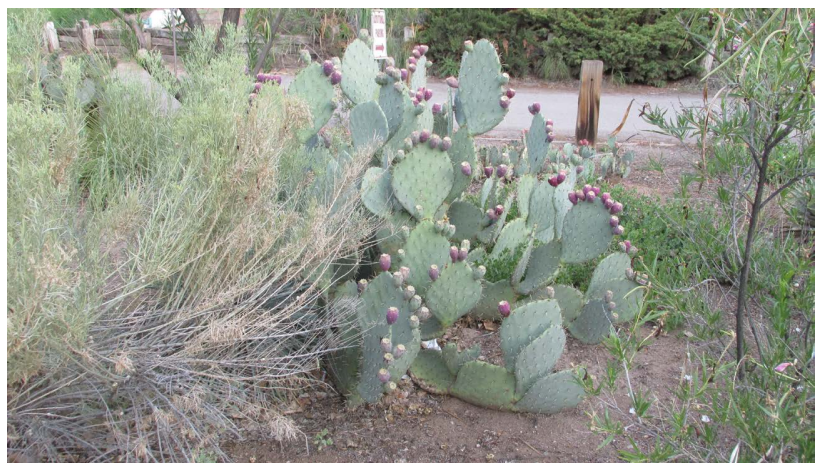

Figure 5. Cactus growing at a park adjacent to the Rio Grande in Albuquerque.

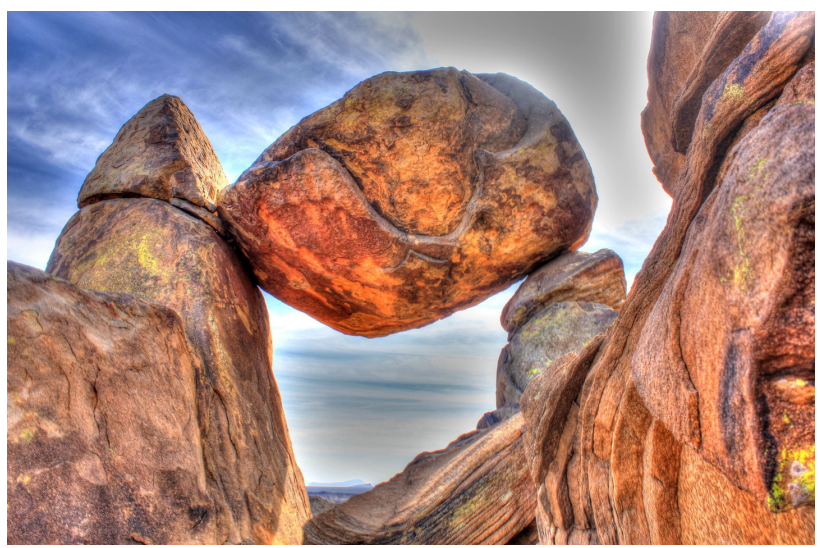

Figure 6. The Rio Grande River watershed in the Big Bend area.

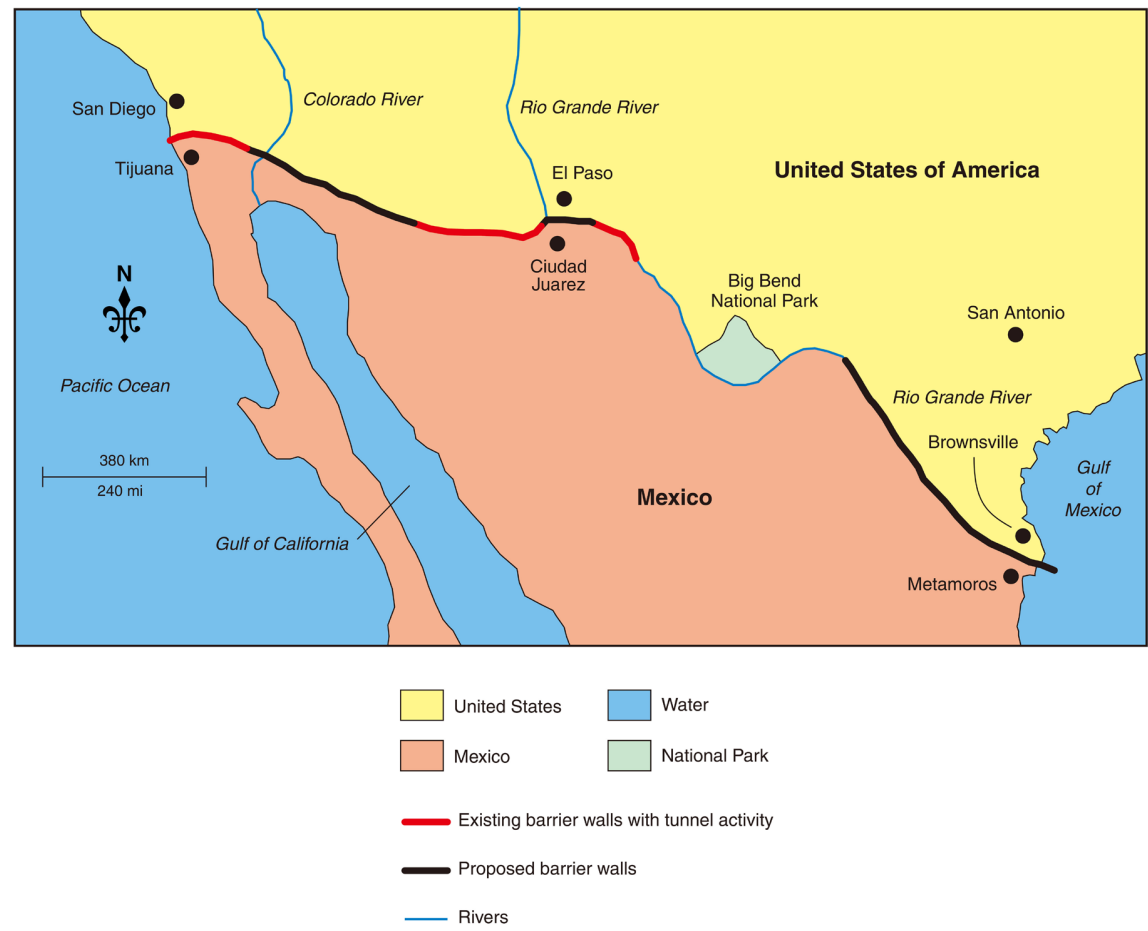

Figure 7. The Mexico-United States border showing the border wall locations and Big Bend State Park. Map by Mic Greenberg. Reprinted with the approval of the OJSS editor. 


\subsection{Geology}

During the past 35 million years the Rio Grande rift (Figure 8), caused by tectonic plates in Earth's lithosphere, moved apart and represents the eastern most example of "widespread stretching" in western United States. The rift consists of three large basins and many smaller basins [6]. The Albuquerque basin, the largest, spans $160 \mathrm{~km}$ from south to north and $86 \mathrm{~km}$ from west to east. The Albuquerque southern basin contains pre-rift volcanic deposits while the central and northern basins contain volcanic rifting eruptions [7]. The sediment fill of the basins consists primarily of mafic volcanic flows (Figure 9) and (Figure 10) and alluvial fans. During rifting these sediments were deposited and are known as the Santa Fe Group. This group contains sandstone, volcanics and conglomerates. Eolian deposits are present in some basins. The Colorado Plateau acts as a microplate and may explain the creation of the Rio Grande rift [8], as a 1 to 1.5 degrees rotation in a clockwise direction, of the Colorado Plateau relative to the North American craton. A craton is defined as a stable and old part of the continental lithosphere and includes the crust and uppermost mantle of ancient crystalline rock covered by younger sedimentary rock.

The Rio Grande rift [9] is a north-trending continental rift zone. The interior of North American craton in the east is separated from the Colorado Plateau in the west. The rift (Figure 8) extends from the state of Chihuahua, Mexico in south to central Colorado in north (Figure 1). The Rio Grande Rift has been important for a long term because it parallels a major river and provides the north-south route.

The White Sands area is in the Tularosa basin, which had lakes with calcium sulfate $\left(\mathrm{Ca} \mathrm{SO}_{4}\right)$ in the water. The lake water eventually evaporated in the arid climate. The dried calcium sulfate (gypsum) crystals (less than $2 \mathrm{~mm}$ in size) were blown by the wind to the northeast corner of the dried lakebed and re-deposited in a series of sand dunes. In a moist climate, the gypsum would have been dissolved by the rainfall. However, rainfall in the White Sands area is less than $20 \mathrm{~cm}$ and dunes deposits were only crusted and are not totally dissolved (Figure 11) and (Figure 12).

\subsection{Native Americans}

Numerous Native American peoples have settled in New Mexico. Their history of settlements, both modern and ancient, is interwoven with the culture and history of the state. Approximately 1500 years ago, ancestral pueblo people migrated south in search of more reliable water sources and built the elaborate cliff dwellings at Bandelier, Mesa Verde and elsewhere across the Four Corners region. Native American peoples eventually established permanent settlements, commonly known as pueblos (Figure 13). They were the ancestors of today's Pueblo people, many of whom still occupy the original villages. Other ancestor groups such as the Apache and Navajo continued their nomadic lifestyles. 


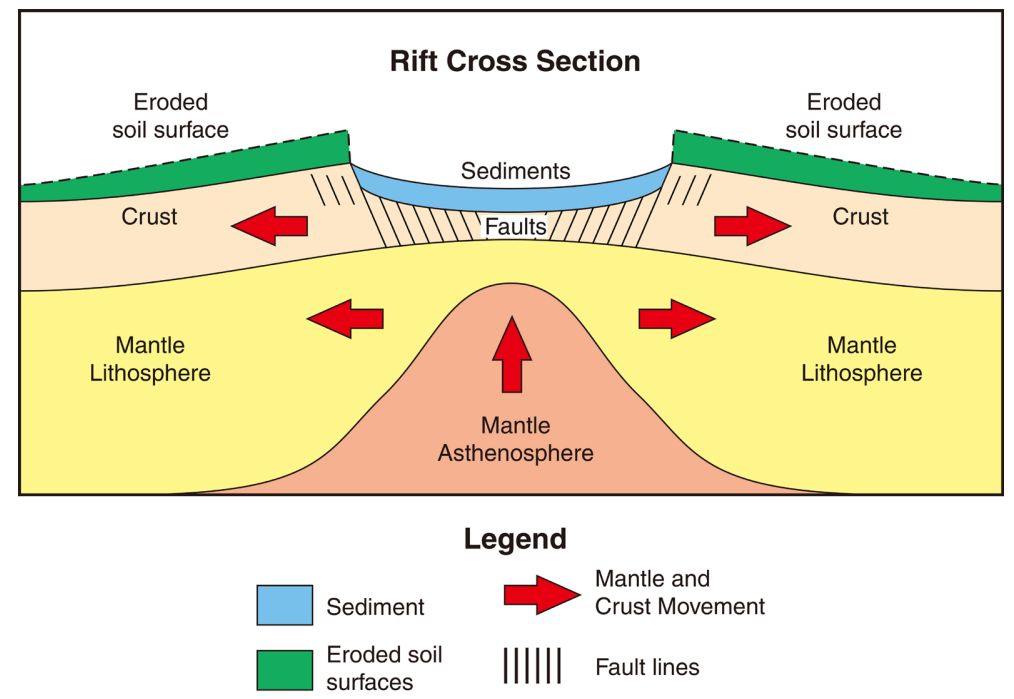

Figure 8. Rift Cross Section. Drawing by Mic Greenberg.

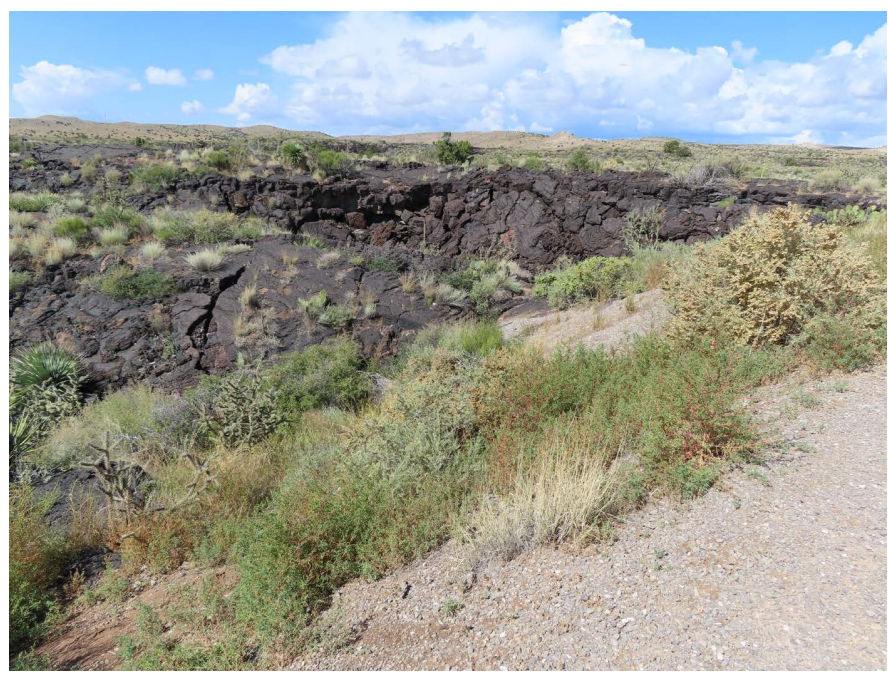

Figure 9. Lava fields in a valley north of White Sands.

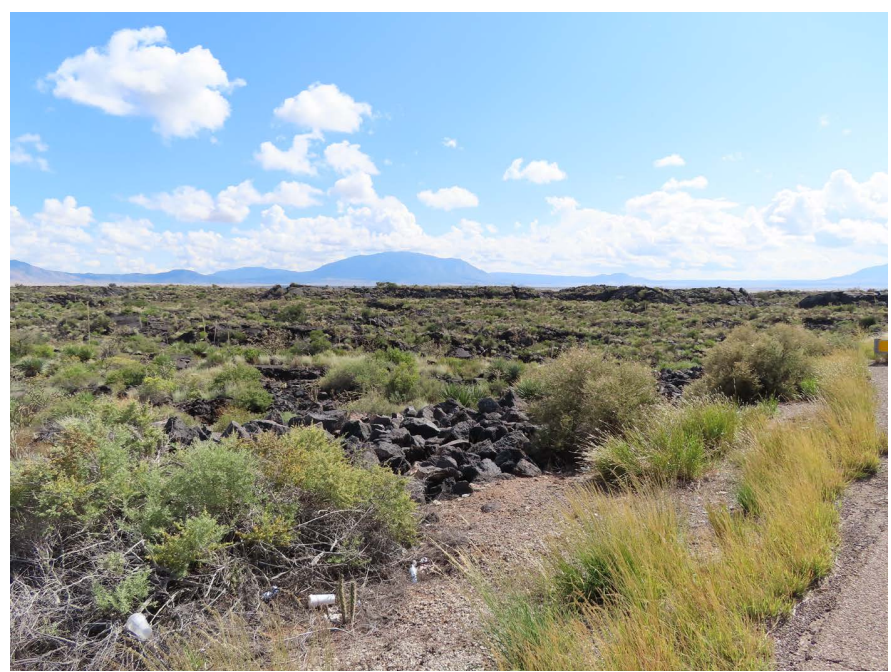

Figure 10. Lava fields in the Rio Grande Valley. 


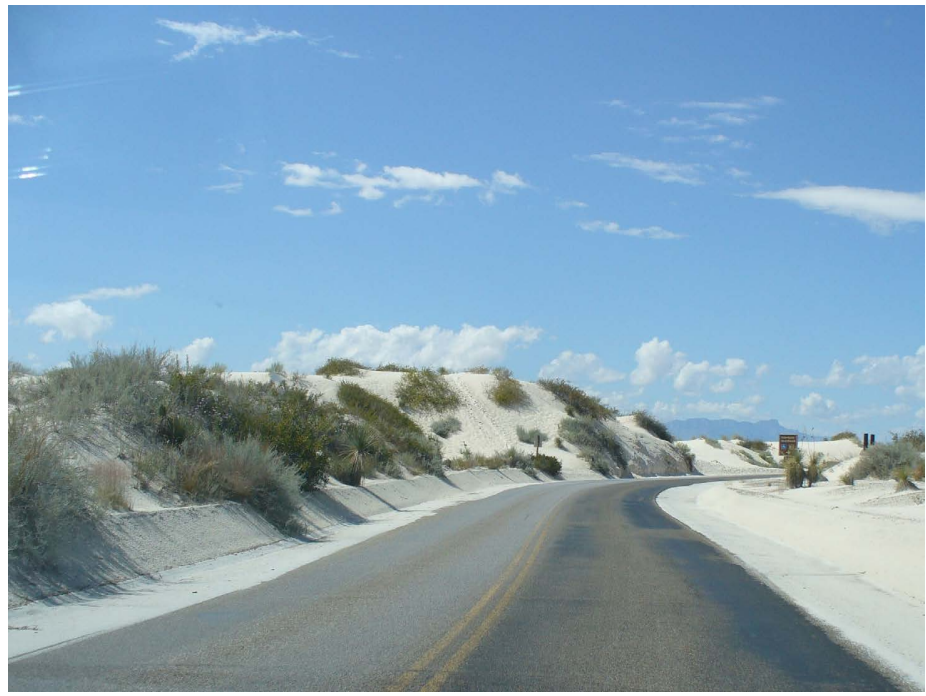

Figure 11. White Sands park. Sand is really gypsum and drifts over roads and has to be plowed back.

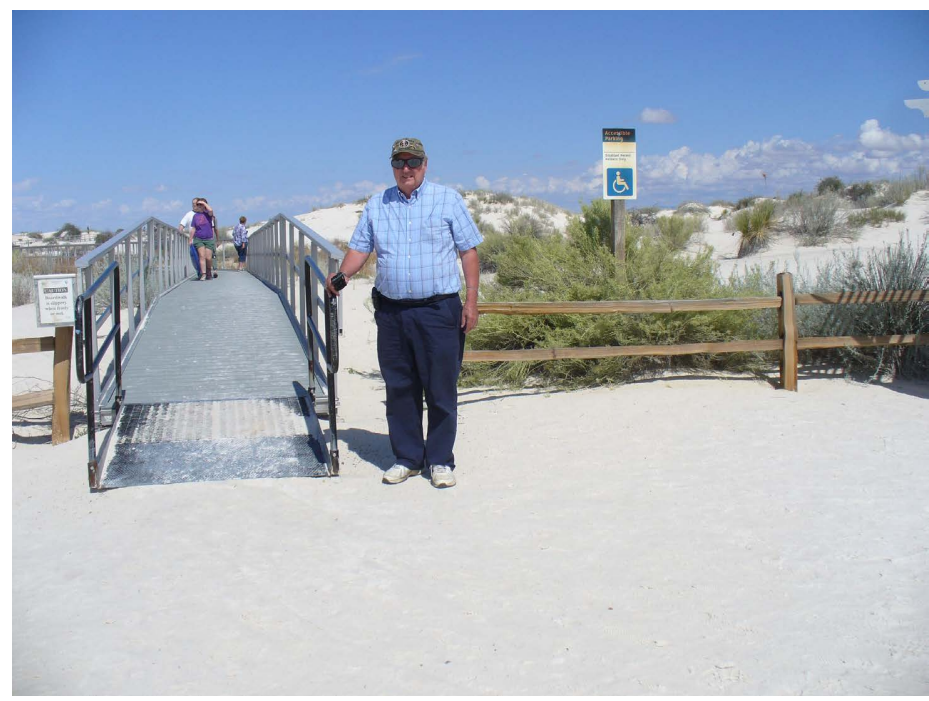

Figure 12. White Sands park. The park service provides trails to cross the sand (gypsum) dunes.

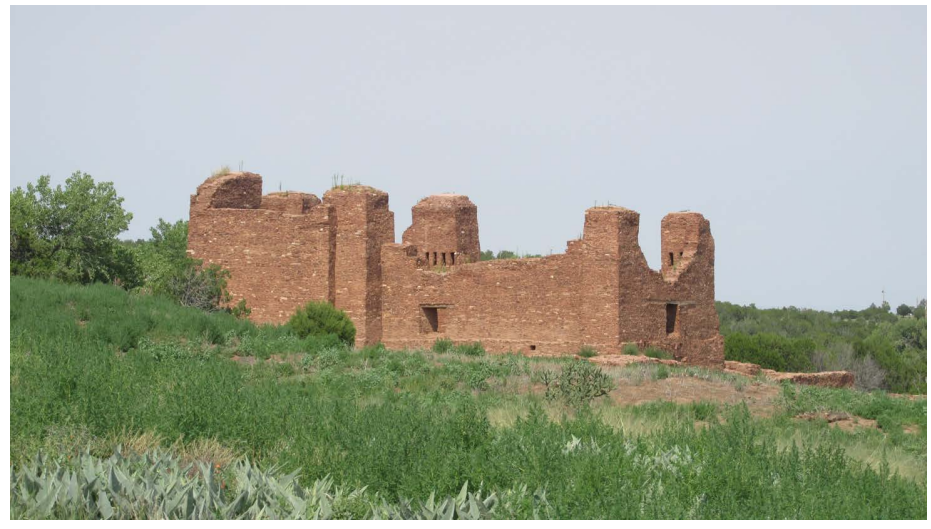

Figure 13. Salinas pueblo mission. 
A Puebloan Native American tribal entity settled in the Ysleta Del Sur Pueblo section in El Paso, Texas. The Puebloan group includes the Southern Tiwa people (Figure 14) who were displaced during the Pueblo Revolt against the Spaniards in 1680-1681. There are 23 Indian tribes located in New Mexico with nineteen Pueblos, three Apache tribes (the Jicarilla Apache Nation, the Fort Sill Apache Tribe, and the Mescalero Apache Tribe) of the Navajo Nation. The nineteen Pueblos are comprised of the Pueblos of Cochiti, Acoma, Jemez, Isleta, Nambe, Laguna, Ohkay, Picuris, Owingeh, Pojoaque, Sandia, San Felipe, Santa Ana, San Ildefonso, Taos, Santa Clara, Santo Domingo, Zia and Zuni.

Native American people, the Karankawa, were concentrated along the coast of the Gulf of Mexico in southern Texas. Several independent seasonal nomadic groups shared the same culture and language. The tribe included the groups called the Guapites (Coapites), Cocos, Cujanes, and Copanes. During the Texan-Mexican War the Karankawa played an important role in the relationships between the Spanish, French and English empires. Commissioned as a captain in 1825, Stephen Austin, who led volunteers, expelled the Karankawa from the Austin land grant. In subsequent years, the Texan colonists repeatedly attacked the Karankawa, who drove them out of their native lands. By the 1840s, the Karankawa split into two groups, one of which fled to the Mexican state of Tamaulipas and the other settled on Padre Island. In 1858, Juan Nepomuceno Coortina led a group of Texan colonists who killed the remaining members of the Karankawa tribe on Padre Island. The Karankawa, as an organized tribe, had become extinct by 1891 .

\subsection{Spanish Exploration of the Rio Grande River Basin}

The first Europeans to explore the Rio Grande were part of an expedition tasked to survey the coast of the Gulf of Mexico in 1519. The name Rio Bravo was first used in 1536 on a map by a royal explorers when Alvar Nunez Cabeza de Vaca traversed the Rio Grande in 1535-1536. In 1540, Francisco Vazquez de Coronado explored the upper Pecos areas and middle Rio Grande. The Rio Grande basin was explored as an agricultural and mining settlement from $16^{\text {th }}$ to $18^{\text {th }}$ centuries. Earliest settlements 1563 in upper Conchos watershed were mining communities. The second colonization was in Lower Rio Grande area in New Mexico was in 1598 and the last settlement was in 1749 along the Lower Rio Grande. The exploration of the Rio Grande Basin was completed in 1779 with Mexican exploration by Juan Bautista de Anza in the San Luis Valley.

\subsection{Evolution of the Border between United States and Mexico}

After Mexico won their independence from Spain in 1821 which extended their land holdings to as far north as the Oregon Territory, the secession of Texas in 1836 created a southern border shift and marked the start of the loss of Mexican territory. In 1844, President James K. Polk, who ran for office on the pledge to "fulfill America's 'Manifest Destiny' which would extend the United States from 


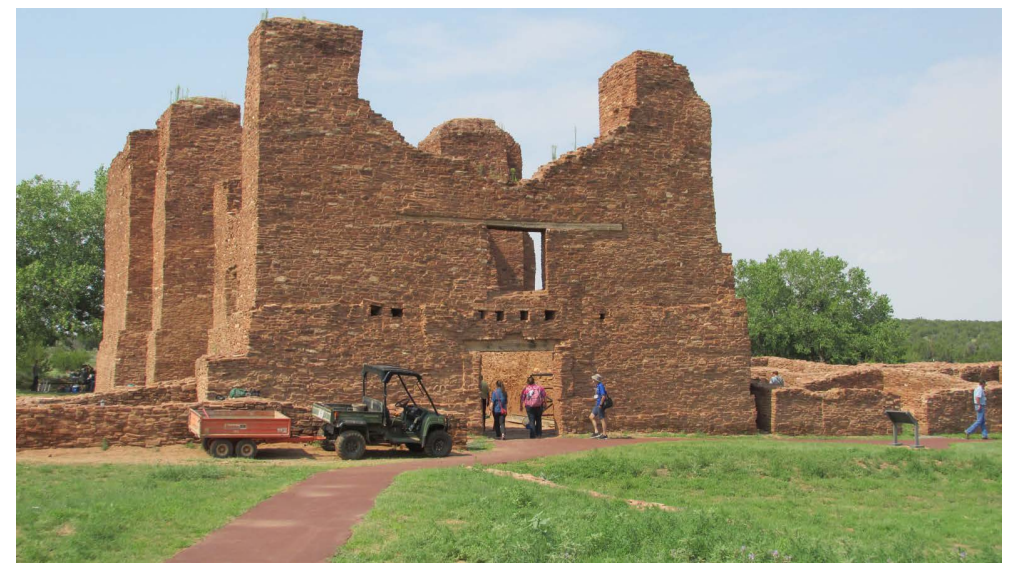

Figure 14. Sabinas Peublo mission. Tiwa people structure.

the Atlantic Ocean to the Pacific Ocean.” The United States attempted to buy New Mexico and California for $\$ 30$ million. After Mexico refused the American offer, relations deteriorated. President Polk then sent 4000 troops into the land south of the Nueces River (near current city of Corpus Christi) and north of the Rio Grande River an area claimed by both countries. The Mexican cavalry attacked the US troops and killed or wounded 16 American soldiers. The United States then declared war on Mexico. After a series of bloody battles, the American forces captured the Mexican capital in September of 1847.

Mexico recognized the United States annexation of Texas under terms of the Treaty of Guadalupe Hidalgo. Mexico eventually agreed to sell additional land including more than one-third of Mexico's territory for $\$ 15$ million dollars. The United States purchased more than 1,300,000 $\mathrm{km}^{2}$ of land that would become the states of California, New Mexico, Arizona, Utah and Nevada as well as parts of the present day Wyoming, Colorado, Kansas and Oklahoma. Therefore, the Mexican-United States War of 1846 resulted in the second greatest purchase of land and second only to the Louisiana Purchase of 1803. The purchase of Alaska from the Soviet Union was probably the third largest purchase of land that became part of the United States.

\subsection{The Establishment of the U.S.-Mexico Border}

The Rio Grande has been the international boundary since 1848 . The modern border took shape following the American-Mexican War. While the Rio Grande formed the dividing line between Mexico and Texas (Figure 7). The border was originally a straight line west from El Paso to the Gila River and then another straight line from Gila River to the Pacific Ocean south of San Diego. Following the Gadsden Purchase of 1853, the borders of New Mexico and Arizona were moved further south from the Gila River. The boundary commission completed its work in the late 1850s.

In 1899 , the Rio Grande gradually changed position and a channel was dug creating Cordova Island, which became a Chamizal dispute. In 1944, the Mexico 
and United States signed a treaty regarding the Rio Grande River. The United States designated the Rio Grande as one of American Heritage Rivers in 1997. A $100 \mathrm{~m}$ wide sandbar formed in mid-2001 at the mouth of the Rio Grande River and the river failed to drain to the Gulf for the first time. The sandbar was dredged but quickly reformed. In 2002, spring rains flushed the sandbar out to sea. By 2003, the river once again flowed into the Gulf of Mexico.

Mexico and the United States share the river under a series of IBWC agreements. The IBWC traces institution roots to 1889 and the most notable agreements were signed in 1906 and 1944. The use of United States water is regulated by the Rio Grande Compact between Colorado, New Mexico and Texas. The Rio Grande water was over-appropriated including the Abiquiu reservoir (Figures 15-17). The section from El Paso downstream through Oyinaga was named "The Forgotten River”.

\subsection{Historic Navigation}

During the American War in 1846, the United States government requisitioned and moved steamboats from the Mississippi and Ohio rivers (Figure 18) and (Figure 19). The steamboats provided transportation for the United States Army

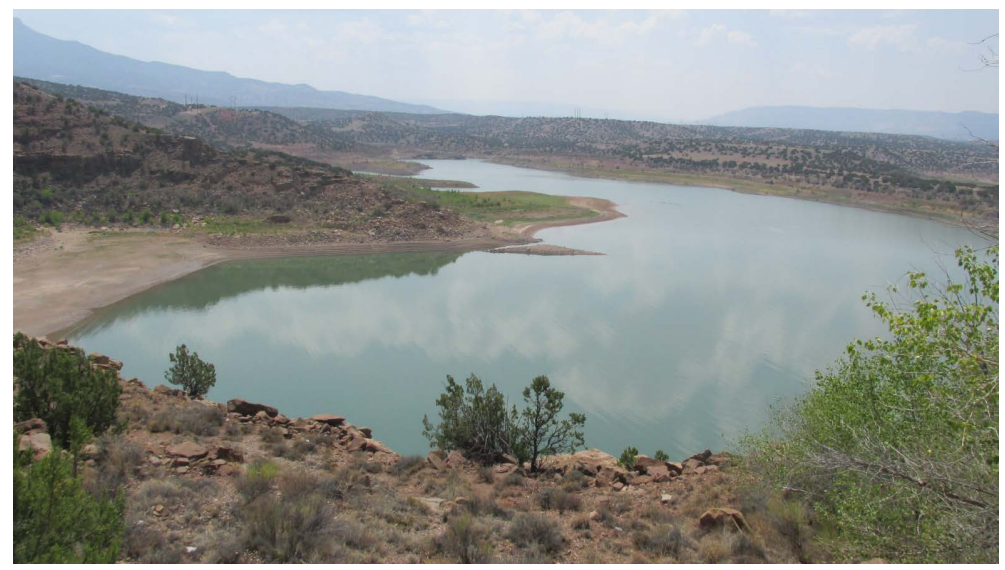

Figure 15. Lake behind the Abiquiu Dam. Water level is low.

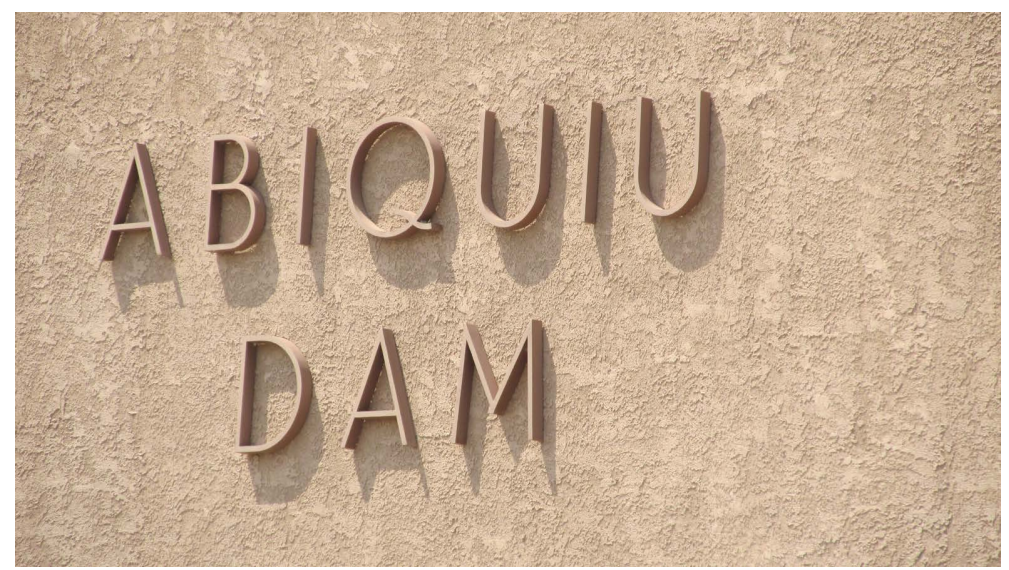

Figure 16. Abiquiu dam sign on Rio Grande. 


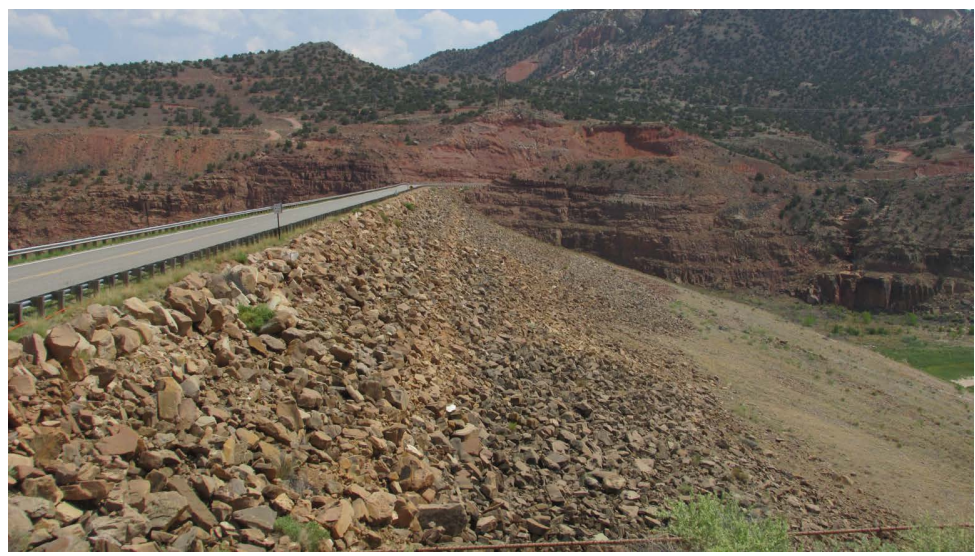

Figure 17. Elevated earthen Abiquiu Dam with road across the top of the structure.

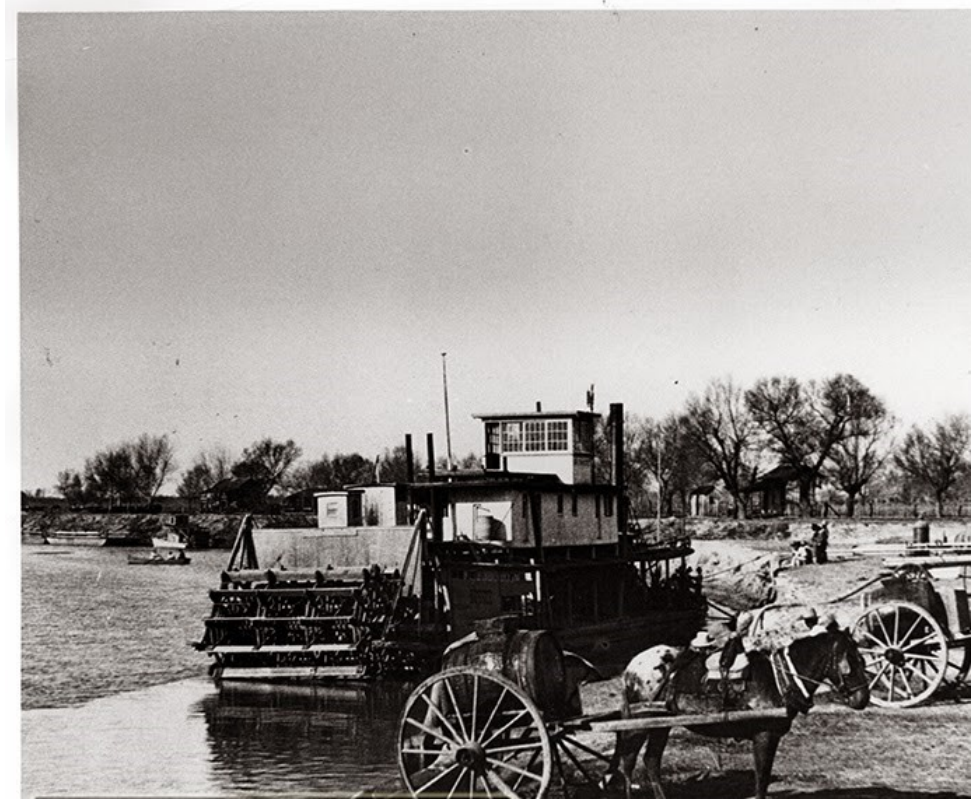

Figure 18. The stern-wheeler steamboat "Bessie" being loaded up at Fort Ringgold in route to Brownsville.

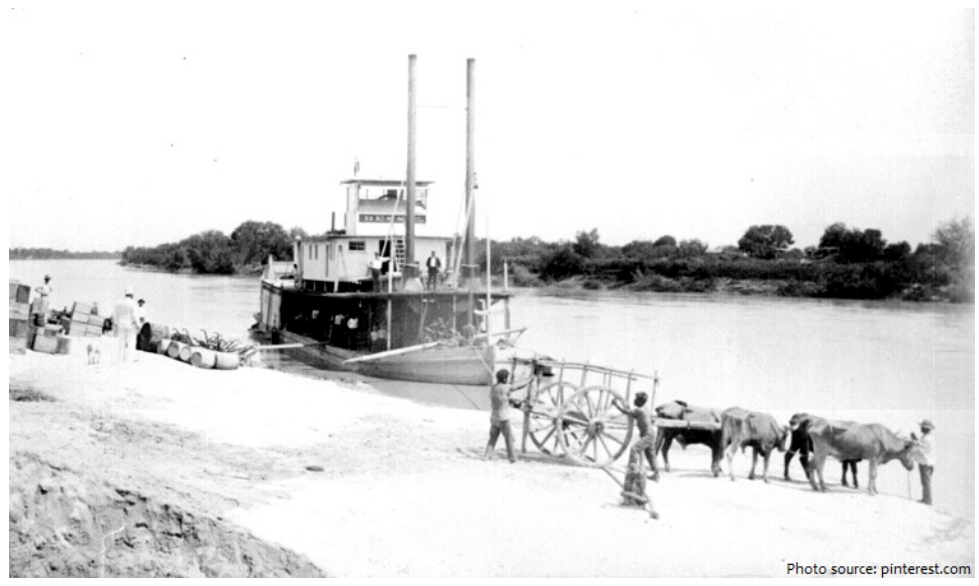

Figure 19. Rio Grande steamboat being loaded. 
during the invasion of Nuevo Leon and Monterrey via Camargo Municipality, Tamaulipas. The USACE recommended only small improvements to make the Rio Grande River passable to El Paso rather than a canal and dam system to enhance shipping. However, these small improvement recommendations were not acted upon or funded. The Rio Grande is still not navigable by cargo barges, ocean-going ships, or smaller passenger boats despite its length and name. It is barely navigable for small recreational boats and only in a few places. At its deepest point along the $1600 \mathrm{~km}$ Rio Grande River, it is only $18 \mathrm{~m}$ deep.

The greatest physical challenges to year-around navigation are obtaining additional sources of water and the $1146 \mathrm{~m}$ elevation difference between the Gulf of Mexico and El Paso and Matamoros, which is a distance of approximately $1600 \mathrm{~km}$ (gradient of $0.75 \mathrm{~m}$ per $\mathrm{km}$ ). The distance is similar to the Ohio River, the Gateway to the West, which has a distance of $1500 \mathrm{~km}$ (gradient of $0.20 \mathrm{~m}$ per $\mathrm{km}$ ) [5]. The number of locks and dams on the Ohio River has recently been reduced to 20 [5] and the flow rate is much higher reducing the need for feeder lakes. The Ohio River is not in an arid climate and its flow rate is much easier to maintain with limited use of feeder lakes. The Lower Rio Grande would probably require approximately 40 to 60 lock and dams to permit shipping from El Paso and Ciudad Juarez to the Gulf of Mexico.

\subsection{The Bridge}

The Brownsville and Matamoros International Bridge (Figure 20), a swing bridge, built in the 1910s, is still used by automobiles to connect the two countries. After the early 1900s, a period of big steamboats, the Rio Grande was no longer open for navigation. At one time, the bridge had rail traffic. In 2015 a bridge, West Rail International Crossing was built about $24 \mathrm{~km}$ west of the Brownsville and Matamoros International Bridge to connect the United States and Mexico by railroad.

\subsection{Port Brownsville}

At the mouth of the Rio Grande on the Mexican side is the large commercial Port of Bagdad (Tamaulipas) (Figure 21). During the American Civil War (1860 to 1865), this port was used by the Confederacy. European warships anchored off shore managed to avoid conflict with the United States Navy. The port is a shallow-draft river port with the deeper-draft cargo ships anchored off shore and the smaller vessels hauling cargo to and from the deep-draft ships. The shallow sandbar at the mouth of the river could not be crossed by the deeper draft cargo ships. At the Port of Tamaulipas, bales of cotton were traded for European military supplies.

\subsection{The Lower Rio Grande Delta}

The Rio Grande Valley includes a river delta, stretching from the Gulf of Mexico to just east of Ciudad Camargo a distance of $200 \mathrm{~km}$. The remaining 1400 
$\mathrm{km}$ of the Rio Grande valley is a large river expanse. The Rio Grande Delta is agriculturally productive. The largest population centers on the south side of the Rio Grande are Matamoros, 0.5 million, Ciudad Acuna, 216 thousand, Nuevo Laredo, 375 thousand, Piedras Negras, 163 thousand and Ciudad Juarez, 1.5 million. The estimated total population of the Rio Grande Valley is approximately 5 million. The northern side of the Rio Grande Valley has a U.S. population of 1.3 million according to the U.S. Census. The largest population centers include Brownsville (Figure 22) and El Paso. With a total population of nearly 6 million, the Rio Grande Valley is a prime candidate for economic development, which could be enhanced by creating a navigation channel to El Paso, a distance of $1600 \mathrm{~km}$, which could be used to ship goods locally, regionally and internationally. The port at Brownsville would probably need to be expanded.

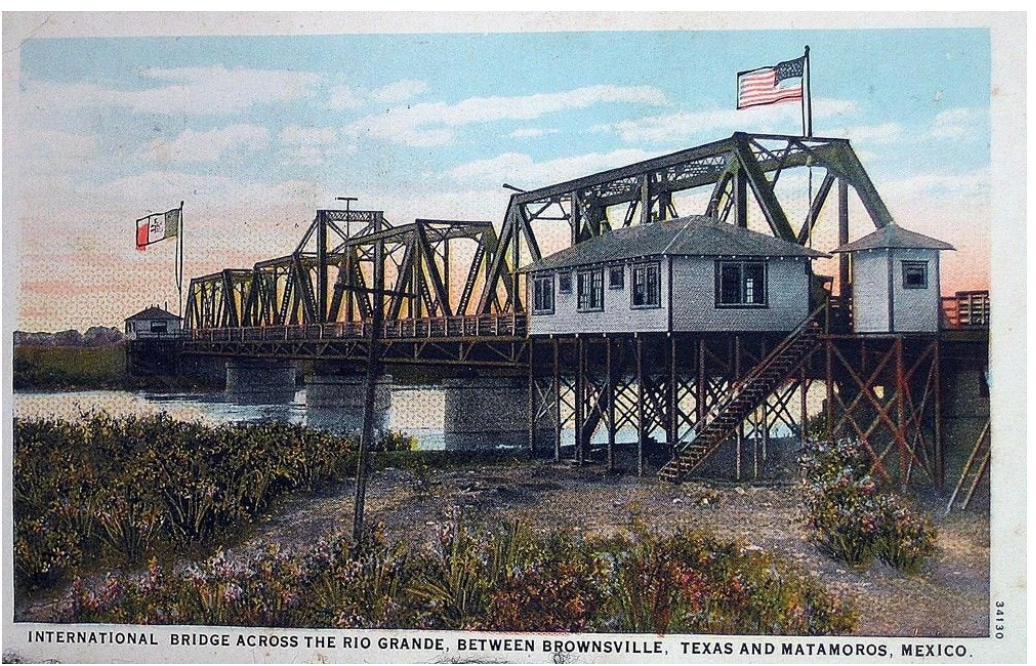

Figure 20. Railroad bridge over the Rio Grande from Brownsville, Texas to Matamoros, Mexico.

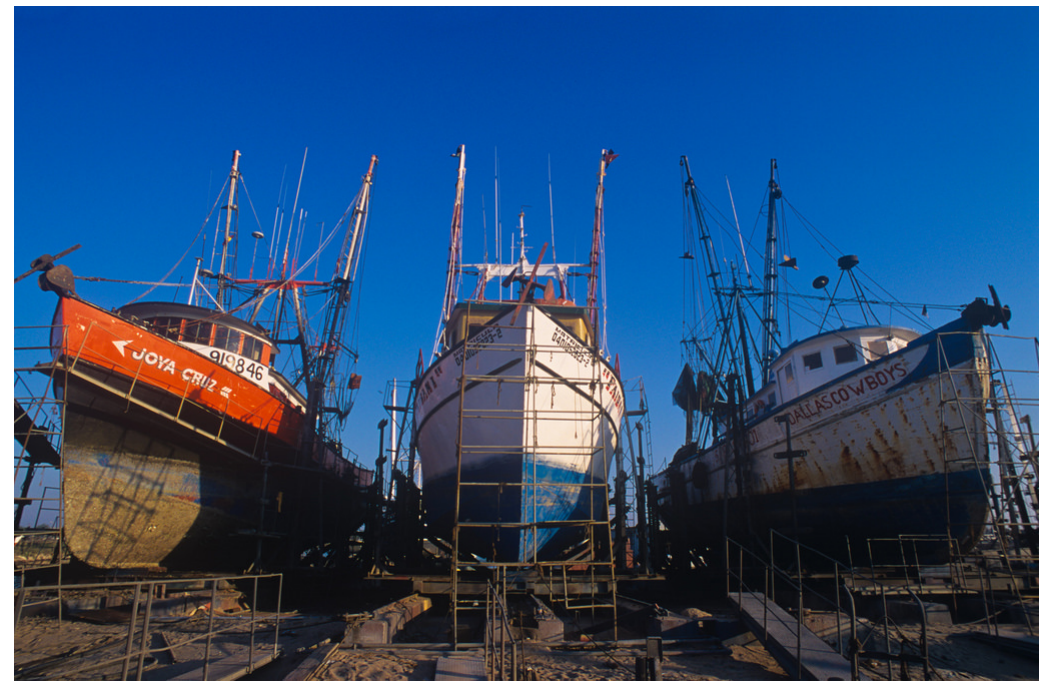

Figure 21. Port Brownsville 3 ships in dry dock. 


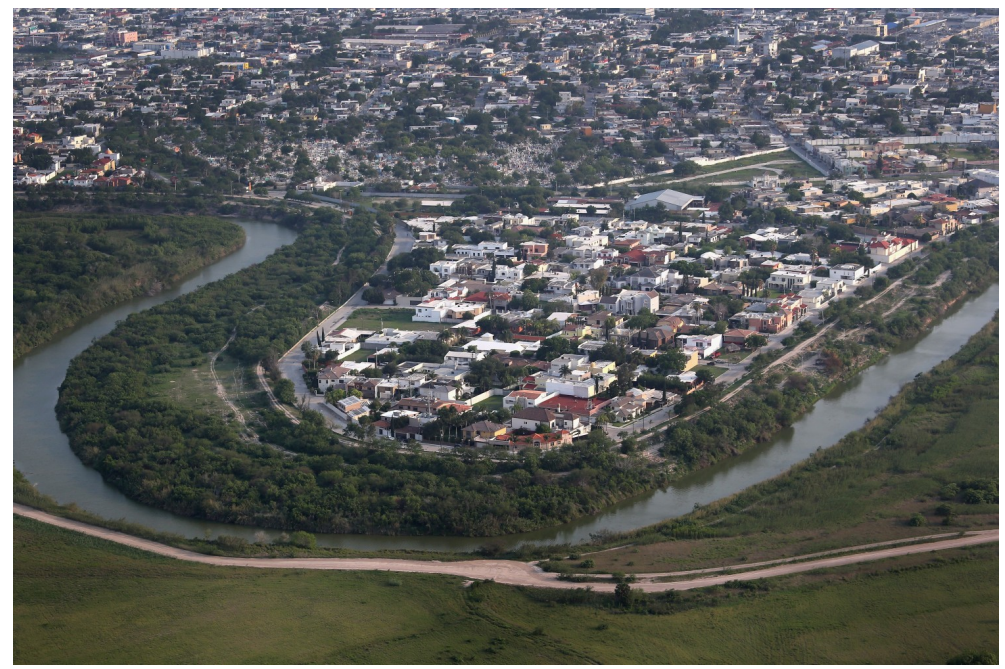

Figure 22. Commercial and residential buildings in Brownsville, Texas on a bend in Rio Grande.

\subsection{Water Supply}

The available water supply in the Rio Grande is disappearing. The Elephant Butte Dam in central New Mexico gates are only opened for a short irrigation season [4]. However, the International Boundary and Water Commission forced the release of stored irrigation water to save cottonwood trees on the riverbanks [10] as part of habitat restoration. Approximately 95 percent of the Rio Grande's average annual flow is claimed for municipal and agricultural use.

Because of growing water needs for the population in Albuquerque and El Paso and Ciudad Juarez (Figure 23) and increased frequency of drought extremes, the river can run dry. As annual snow packs shrink and evaporation rates increase, the upper Rio Grande watershed will collect 30\% less water. The Rio Grande silvery minnow is an endangered species. Its habitat is limited to the middle sections of the Rio Grande River near Albuquerque, New Mexico (Figure 24). The Rio Grande has an average annual yield of 3.2 billion $\mathrm{m}^{3}$ of which only $1 / 3$ reaches to the Gulf (Figure 25) prior to building the Falcon Dam, near Rio Grande City in 1953. The discharge is now $85 \mathrm{~m}^{3}$.

Irrigation (Figure 26) has been practiced in the Rio Grande basin since prehistoric times, mostly by the Pueblo Indians of Mexico. Increased population made water treaties (1905-1907 and 1944-45) between United States and Mexico necessary. There was a Rio Grande Compact in 1939 between New Mexico and Texas. Essentially all of the $37,000 \mathrm{ha} \cdot \mathrm{m}^{-1}$ of the upper Rio Grande water (including $7400 \mathrm{ha} \cdot \mathrm{m}^{-1}$ allotted to Mexico by treaty) is consumed in the basin.

The international Amistad Dam, located near the confluence of Devils River, under terms of United States-Mexico treaty, produces considerable amounts of electricity. Excluding areas irrigated above the reservoirs, the river provided more than half of the irrigated lands in Mexico. The river provides water for 850,000 ha of cropland. The leading irrigated crops vary from alfalfa and potatoes in Colorado to pecans grapes and cotton in the southern New Mexico. In El 
Paso, Texas and Juarez, Mexico regions, cotton, citrus fruits and vegetables are grown and would benefit from reliable shipping to the Gulf of Mexico.

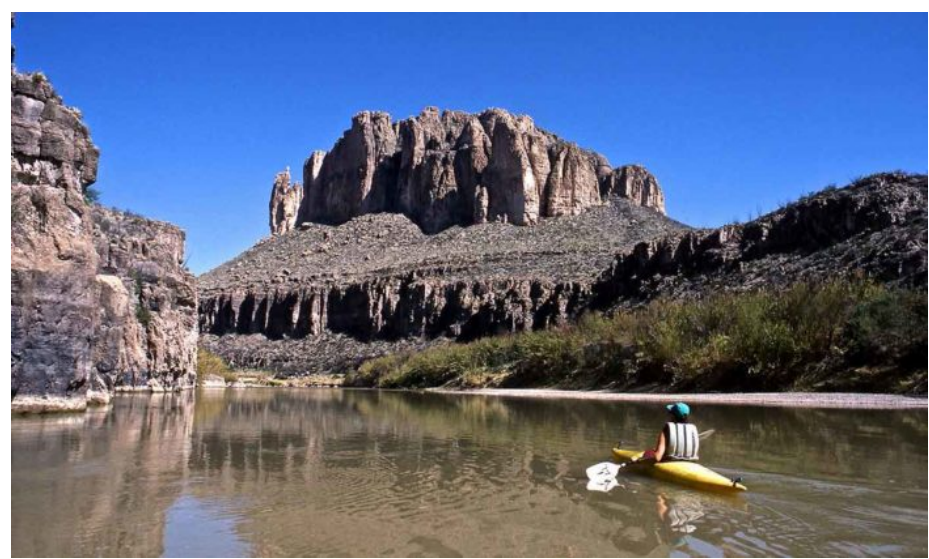

Figure 23. Recreation use of the Rio Grande at Big Bend State Park in Texas.

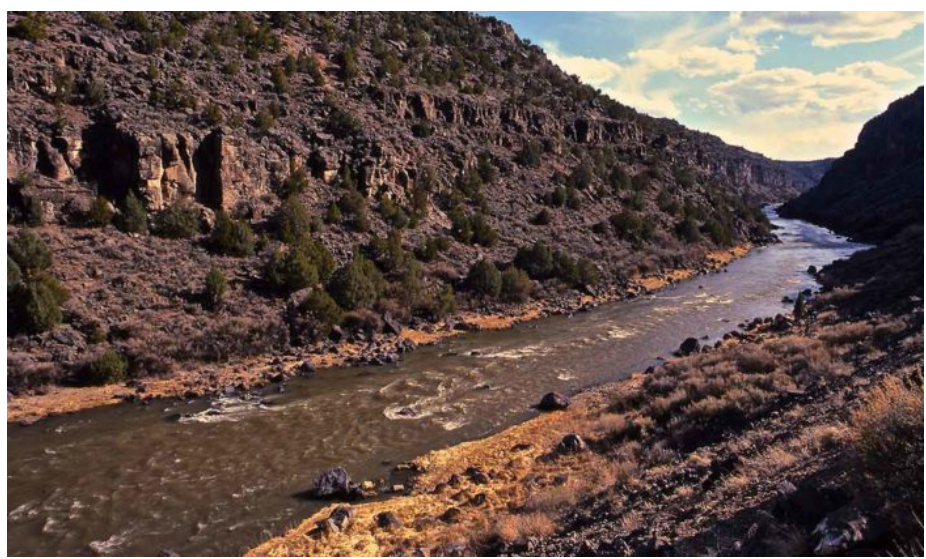

Figure 24. Rio Grande near Dunn Bridge rocky canyon walls.

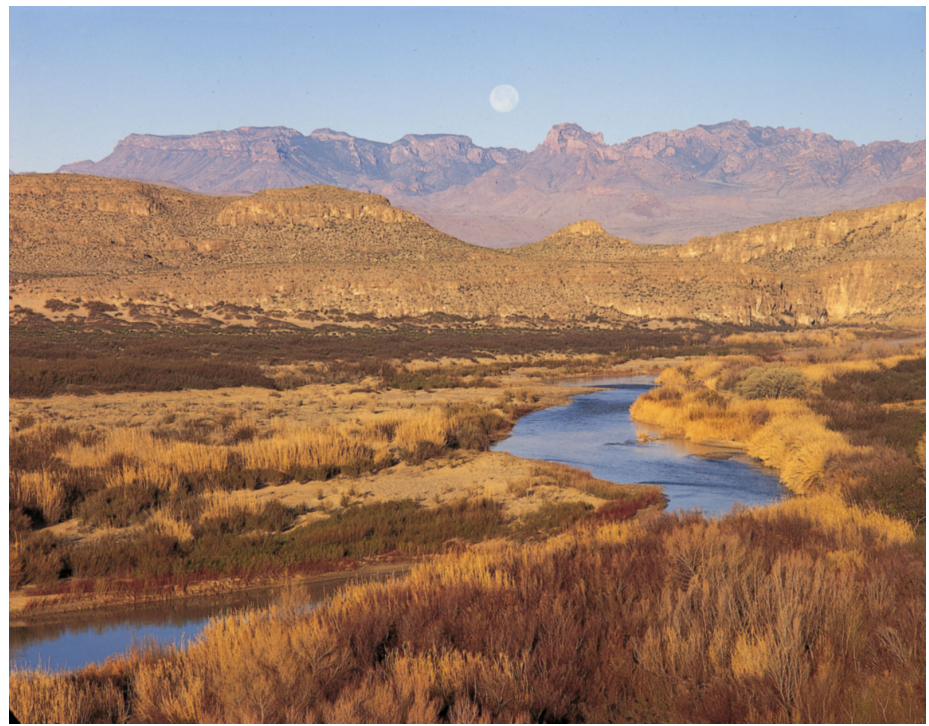

Figure 25. Desert adjacent to Rio Grande and the Chios Mountains. 


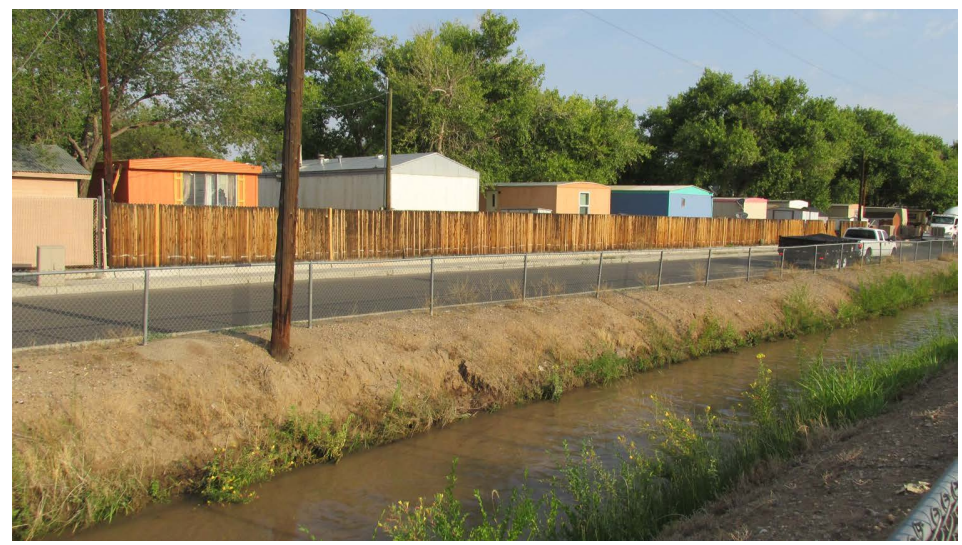

Figure 26. Irrigation and waterways -trailer park in Albuquerque, New Mexico.

After animal husbandry (Figure 27) and agriculture, the leading industries are mining for petroleum, natural gas, uranium ore, coal, gold, lead, silver, gypsum and potash that could be enhanced by barge shipping on the Lower Rio Grande River. Recreation activities (Figure 28) and (Figure 29) are included year-around state and national parks (Figure 23), monuments, dude ranches, rafting, fishing, ballooning (Figure 28) and hunting.

Water conservation practices already in place will need to be enhanced for both the irrigated agricultural areas and the urban areas. Demand for water is exceeding the availability and the situation is only going to get worse as the population of the entire Rio Grande valley in both the United States and Mexico continues to rapidly expand.

\subsection{A Lock and Dam System Extending from Brownsville, Texas to El Paso, Texas}

The Rio Grande was historically used for navigation and the shipping of agricultural products (Figure 30) and goods on the Lower Rio Grande River near Brownsville and Matamoros. However, the small-scale USACE proposal to improve navigation to El Paso and Ciudad Juarez was never funded or developed. There are millions of people living in the Rio Grande valley between Brownsville and Matamoros and Ciudad Juarez and El Paso. The low cost shipping of produce and goods would provide an economic boom to the Rio Grande Valley.

Another mitigation objective is to get the USACE to build a lock and dam system on the Lower Rio Grande, which would permit year-around shipping of produce and goods similar to the Ohio River lock and dam system [5]. The Ohio River is approximately $1500 \mathrm{~km}$ long and has an elevation change of $300 \mathrm{~m}$ between Pittsburgh, Pennsylvania and Cairo, Illinois. It has a gradient of $0.20 \mathrm{~m}$ per $\mathrm{km}$ and which currently requires 20 locks and dams. The other environmental obstacles are to having sufficient year around water to supply the lock and dam system during dry periods. This could require water conservation practices in addition to more reservoirs and possibly even a pipeline to transport river water with low salt content from a point near the mouth of the Rio Grande River 
to avoid high salt water content to the Upper Rio Grande River, a distance approaching 2000 to $3000 \mathrm{~km}$ similar to the oil pipeline in Alaska [11] which extends a distance of $2000 \mathrm{~km}$. Without additional urban and agricultural conservation practices, the extra water would either be used or evaporated in the arid climate and might not change the flow volume in the Lower Rio Grande Valley.

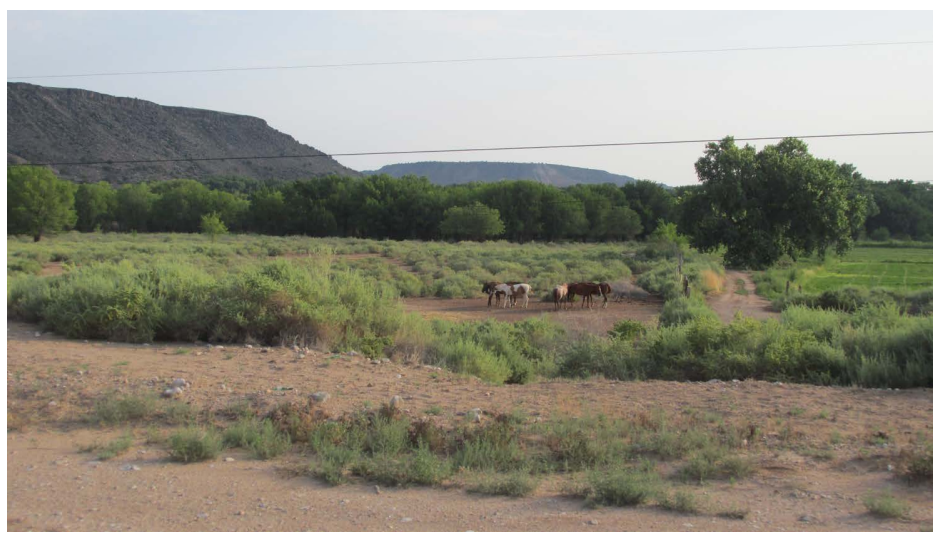

Figure 27. Horse pasture along the Upper Rio Grande.

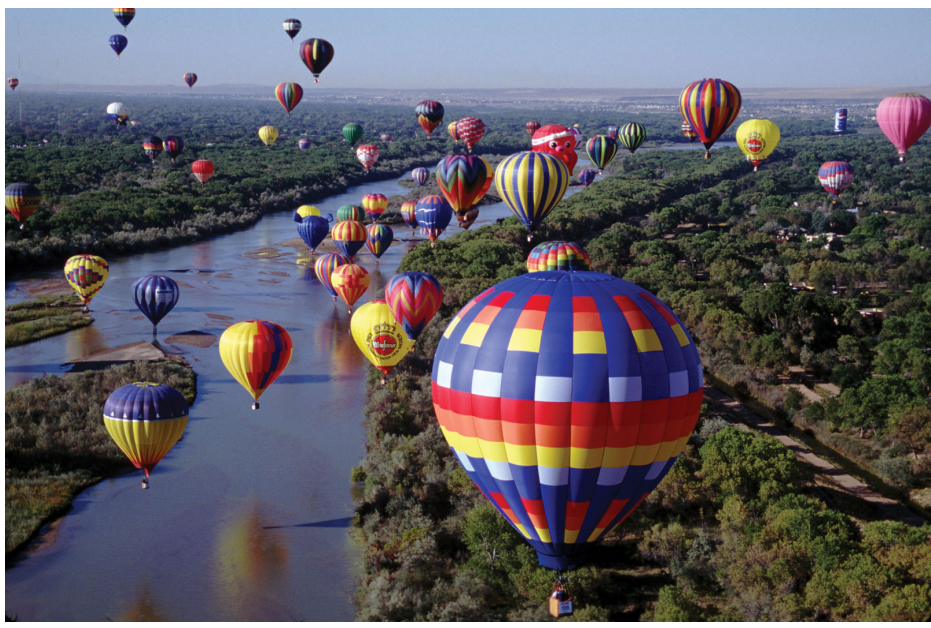

Figure 28. Balloons over the Rio Grande Valley and River south of Albuquerque.

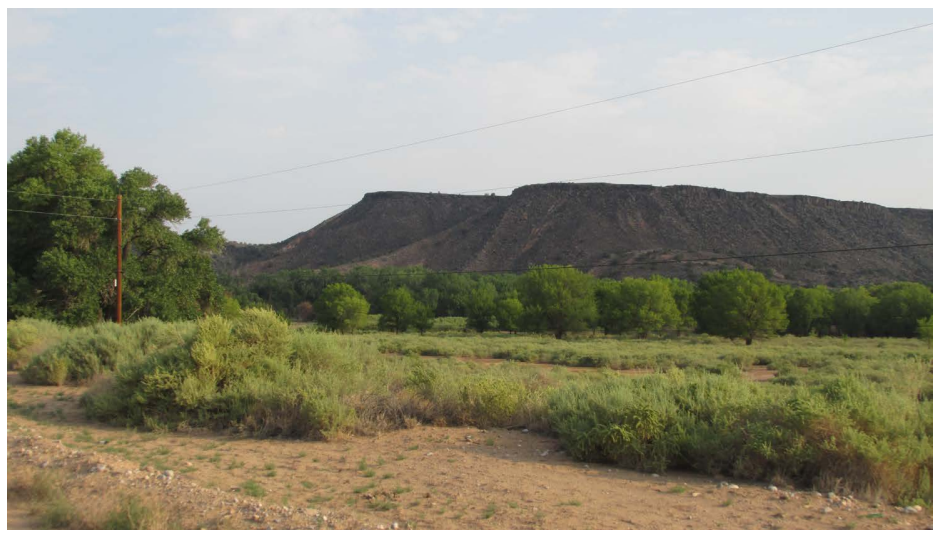

Figure 29. Buttes in national park along the Upper Rio Grande. 


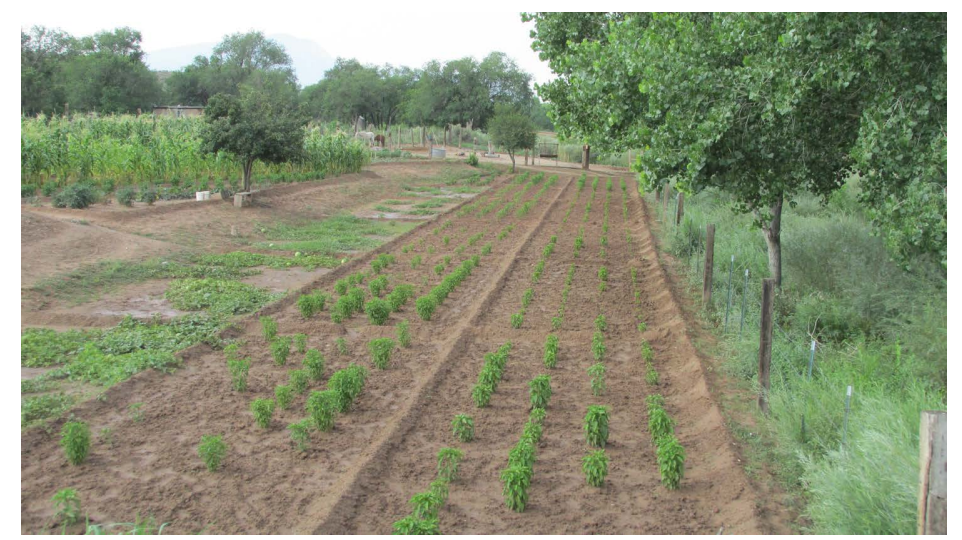

Figure 30. Garden plots along the Rio Grande north of Albuquerque, New Mexico.

\subsection{Recreation}

Stretches of the Rio Grande including sections of the Rio Grande near Dunn Bridge, New Mexico and Borlon Canyon, Texas were designated a National Wild and Scenic River (Figure 6). The Rio Grande River borders the Big Bend National Park and two National Monuments.

Hundreds of kilometers of the Rio Grande River is sucked dry and redirected to flow into irrigation before it reaches El Paso. The river is replenished by the Mexico's Rio Conchos just upstream from the $190 \mathrm{~km} \mathrm{~S}$-curve of the Big Bend Park and enough water is available to feed a $307 \mathrm{~km}$ segment of the 1978 of the Wild and Scenic River. Big Bend Park's Santa Elena and Mariscal canyon has 450 $\mathrm{m}$ of towering limestone walls (Figure 31 ).

\subsection{Thornforest Restoration, Forest Fires and Gully Erosion Control Structures}

The construction of the American border wall is contributing to the destruction of the Thornforest habitat. The American Forests have planted 2 million thornscub trees and other native plants. The Thornforests traditionally have drawn millions of bird watchers each year. The birds include the hawk, green jays and Altamira orioles. In the Lower Rio Grande Valley, ecotourism generated more than $\$ 340$ million in 2014. However, COVID-19 and border wall issues have eliminated most of the bird watching. Forest fires are difficult to control in the dry climate and can result in significant trees loss (Figure 32) with soil erosion (Figure 33). The situation requires mitigation including stream erosion controls and stream bank stabilization and gully structures (Figure 34) and (Figure $35)$.

\subsection{U.S. Immigration Policy}

Following the American-Mexican War, citizens from both countries traveled freely across the border. There were no federal limits on immigration for decades. After the passage of the Chinese Exclusion Act of 1882, it was Chinese, not Mexican; immigrants that vigilante groups and American authorities first sought 


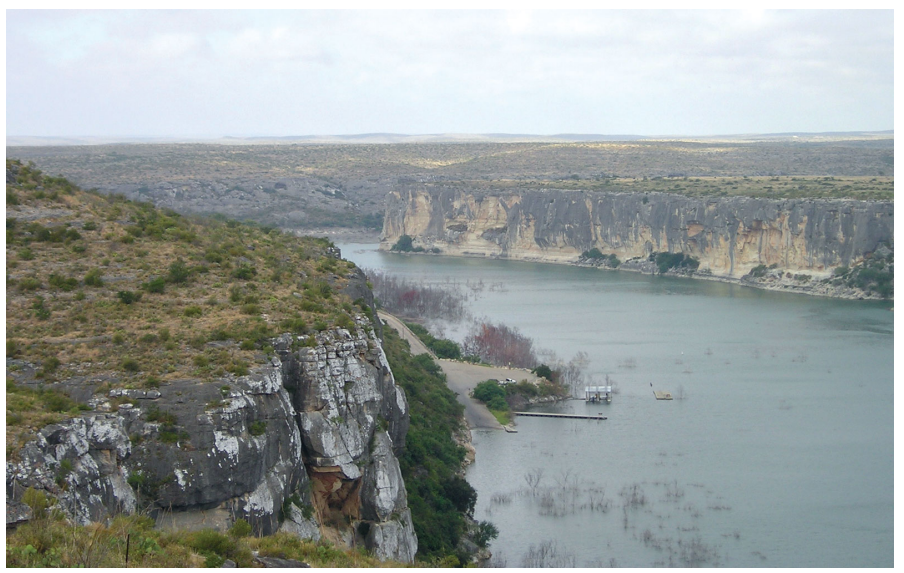

Figure 31. Pecos River cutting through limestone.

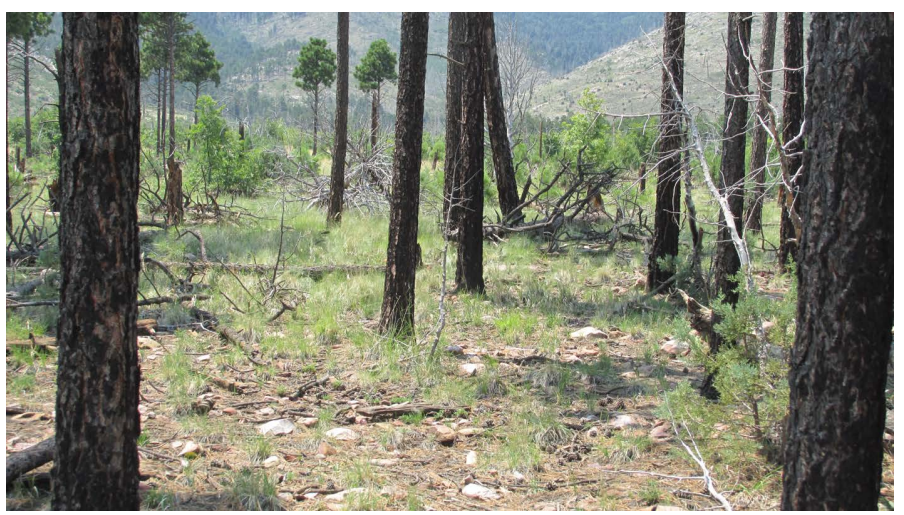

Figure 32. Burnt forest east of Albuquerque, New Mexico.

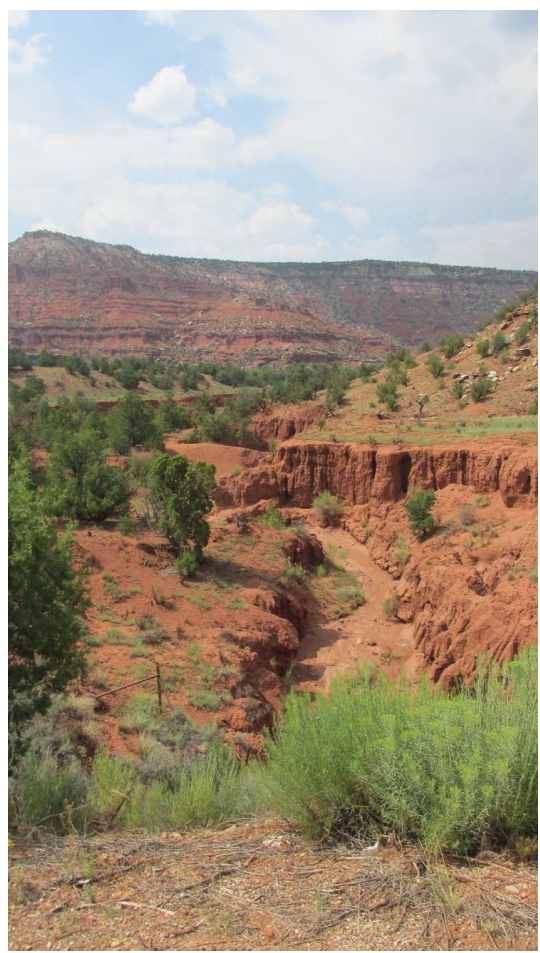

Figure 33. Dry eroded streambed northwest of Albuquerque. 


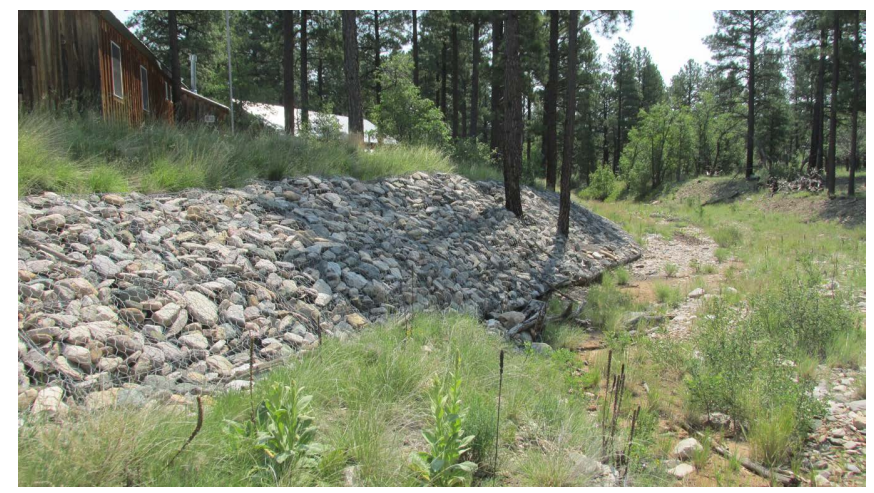

Figure 34. Gully erosion control structures on tributary streams of the Upper Rio Grande.

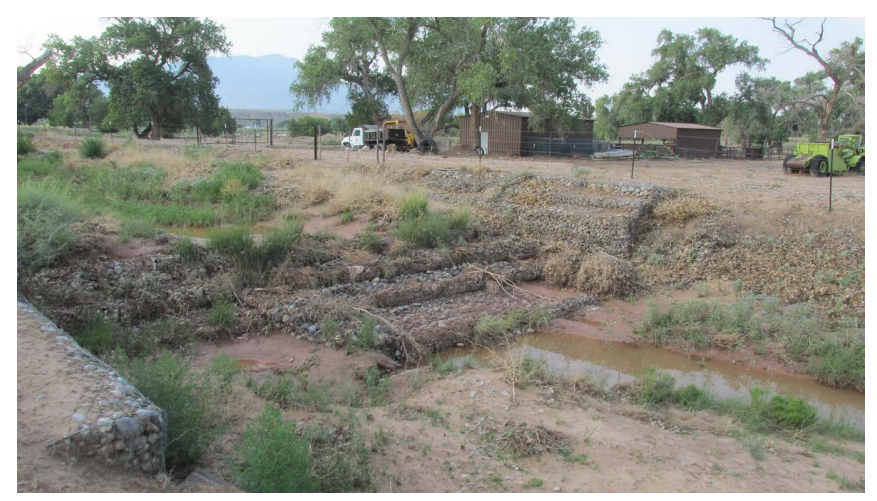

Figure 35. Stream bank erosion control structure on Rio Grande tributary streams.

to keep from illegally crossing the southern border. "One of the ways that immigrants from China would try to get across the border was to learn a few words of Spanish and disguise themselves as Mexican" [12].

"Restrictions on the movement of Mexican citizens were not particularly enforced by the U.S. government until the decade of the Mexican Revolution in the 1910s when large numbers of refugees came to escape the war and there was a large demand for Mexican labor," [12]. In 1916, the United States started enforcing refugee movement restrictions following Mexican revolutionary Poncho Villa's deadly raid on Columbus, New Mexico and the subsequent publication of the Zimmerman Telegram, proposing a World War I military alliance between Germany and Mexico. The United States deployed soldiers to patrol the boundary along with government-sanctioned "home guards" and Texas Rangers to tightened border security.

\subsection{Border Wall or Fence}

The border between the Mexico and United States is nearly $3200 \mathrm{~km}$ stretching from the Gulf of Mexico to the Pacific Ocean and borders California, New Mexico, Arizona and Texas. The longest section of the border is the $2020 \mathrm{~km}$ border east of El Paso, Texas (Figure 7) to Brownsville, Texas. This part of the international boundary is a natural geographic barrier. However, the river often dries 


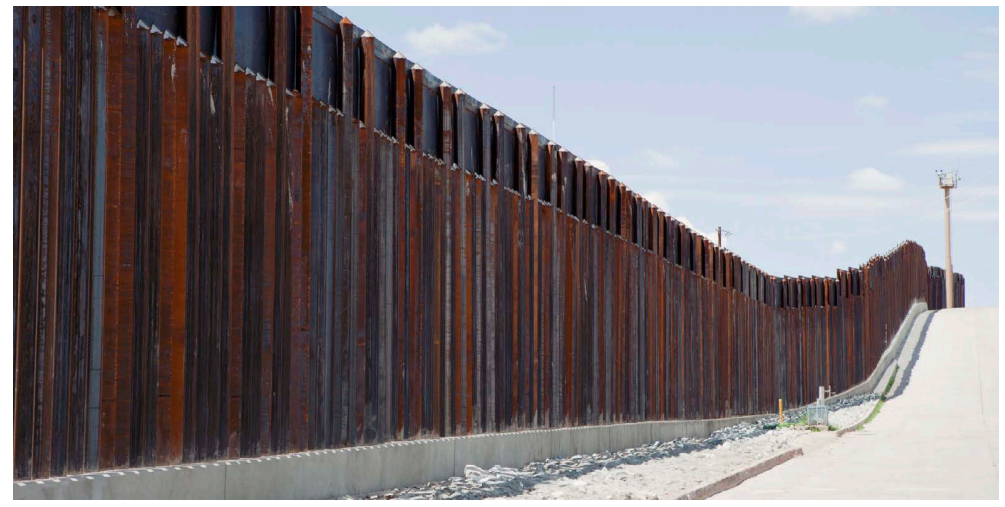

Figure 36. Border wall on the Mexico-United States border.

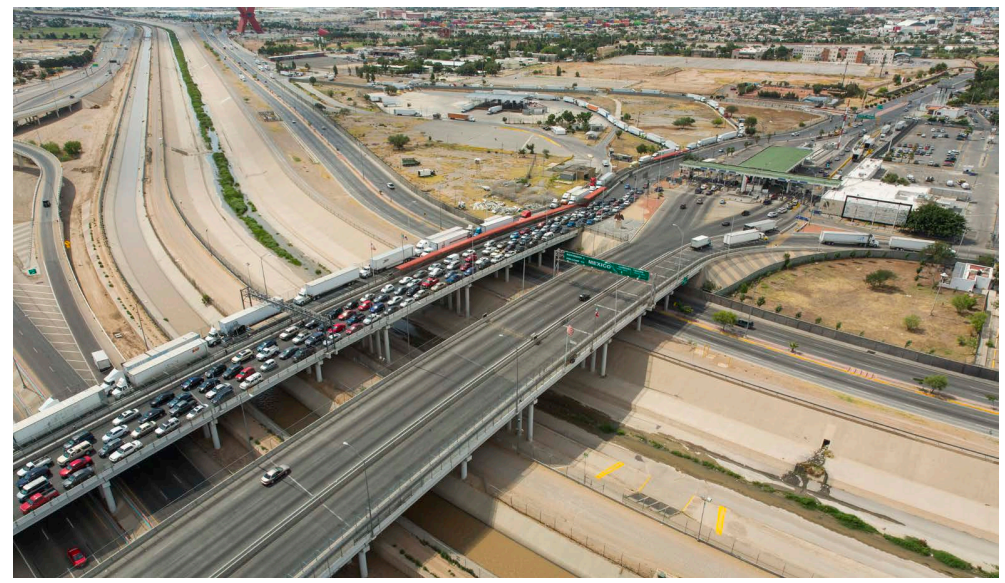

Figure 37. Highway Bridge of Americas over the Rio Grande between El Paso and Ciudad Juarez.

up but continues to serve as the official border. Most of the $1130 \mathrm{~km}$ of chain link, barbed wire, post-and-rail and wire mesh fencing and wall (Figure 36) have been built along the $1290 \mathrm{~km}$ Rio Grande west of El Paso [13]. United States plans after 2018 were to expand the fence and wall building effort along the Rio Grande River (Figure 37) between Brownsville and El Paso (Figure 36).

\section{Summary and Conclusions}

During the 1830s and 1840s, there was a border dispute between Mexico and Republic of Texas. Mexico claimed the border north to Nueces River rather than the Rio Grande. After Texas had become a state, this disagreement provided part of rational for the 1846 United States invasion of Mexico. Since 1848, the Rio Grande has been an international river boundary.

The longest section of the border is the $2020 \mathrm{~km}$ of the Rio Grande River and is the international border east of El Paso, Texas and extending to Brownsville, Texas. This part of the international boundary is a natural physical barrier created by the Rio Grande. However, the river often dries up and is no longer a natural barrier to illegal immigration.

A lock and dam system with feeder lakes is needed to re-create navigation on 
the Rio Grande River and to re-establish shipping, commerce and international trade which would benefit both Mexico and the United States as well as the 6 million United States and Mexico residents living in the Rio Grande Valley. The creation of a lock and dam system on the Lower Rio Grande would have a secondary homeland security benefit. The Rio Grande River would again become a natural physical barrier to illegal immigration. When a wall is built, it is often followed by soil tunneling if the soil and parent materials and depth to water table are all favorable. Historically, there has been little tunneling under the Rio Grande River, due in part to the potential flooding. In addition, soil tunnels built in porous and unstable unconsolidated soil and parent material can flood.

The Mexico and United States share the river under a series of IBWC agreements. The IBWC traces institutional roots extending back to 1889. Outdoor recreation is now the third leading industry behind only agriculture and mining. If the once mighty Rio Grande is ever going to be restored it will need a lock and dam system with feeder lakes and a water pipeline in addition to a balanced approach to water management, including efficiency measures and aggressive conservation.

\section{Acknowledgements}

Published with funding support from NRES and the USDA, NIFA, Water Division (Hatch Project 875-979) and with the approval of the Director of the Illinois Office of Research, College of Agricultural, Consumer, and Environmental Science, University of Illinois, Urbana, Illinois.

\section{Conflicts of Interest}

The authors declare no conflicts of interest regarding the publication of this paper.

\section{References}

[1] Benke, A.C. and Cushing, C.E. (2005) Rivers of North America. Academic Press, Cambridge, Massachusetts, 186-192.

[2] Hogan, P. (1991) Great River: The Rio Grande in North American History. 4th Edition, Wesleyan University Press, Hanover, NH.

[3] Huff, M. (2005) Steamboats Big Part of Valley's Start. Brownsville Herald.

[4] Metz, L.C. (2010) Rio Grande. The Handbook of Texas Online. Retrieved 17 December 2018.

[5] Morton, L.W. and Olson, K.R. (2020) Securing the Nation's Infrastructure: The Ohio River. Journal of Soil and Water Conservation, 74, 5A-11A. https://doi.org/10.2489/jswc.74.1.5A

[6] Chapin, C.E. and Cather, S.M. (1994) Tectonic Setting of the Axial Basin of the Northern and Central Rio Grande Rift. The Geological Society of America, 291, 1-3. https://doi.org/10.1130/SPE291-p5

[7] Kluth, C.F. and Schaftenar C.H. (1994) Depth and Geometry of the Northern Rio Grande Rift in the San Luis Basin, South-Central Colorado. The Geological Society of America, 291, 27-37. https://doi.org/10.1130/SPE291-p27 
[8] Russel, L. and Snelson, S. (1994) Structure and Tectonic of Albuquerque Basin Segment of the Rio Grande Rift: Insights from Reflection Seismic Data. The Geological Society of America, 291, 83-112. https://doi.org/10.1130/SPE291-p83

[9] Hill, K. (2005) The Rio Grande Rift: A Continent Stretched Like Taffy. New Mexico State University, Las Cruces, New Mexico, News Release.

[10] Olson, K.R. and Lang, J.M. (2021) The Disappearing Colorado River: Historic and Modern Attempts to Mange the Lifeline of the United States southwest. Open Journal of Soil Science, 11, 538-566. https://doi.org/10.4236/ojss.2021.1111027

[11] Olson, K.R. and Lang, J.M. (2020) Sediment Delivery by the Yukon River to the Yukon Flats, Yukon Delta and the Bering Seas. Open Journal of Soil Science, 10, 410 442. https://doi.org/10.4236/ojss.2020.109022

[12] St. John, R. (2011) Line in the Sand: A History of the Western U.S.-Mexico Border. Princeton University Press, Princeton, NJ. https://doi.org/10.23943/princeton/9780691141541.001.0001

[13] Olson, K.R. and Speidel, D.R. (2021) Why Does the Repaired Len Small Levee, Alexander County, Illinois, US Continue to breach during Major Flooding Events? Open Journal of Soil Science, 10, 16-43. https://doi.org/10.4236/ojss.2020.101002 